\title{
Exploring Solutions for the Negative Impact of US Quantitative Easing on Taiwan
}

\author{
Chien-Jung Ting \\ Department of International Business and Trade, Shu-Te University, Taiwan \\ Email: cjting@stu.edu.tw
}

How to cite this paper: Ting, C.-J. (2018) Exploring Solutions for the Negative Impact of US Quantitative Easing on Taiwan. Journal of Mathematical Finance, 8, 14-26. https://doi.org/10.4236/jmf.2018.81002

Received: November 19, 2017

Accepted: January 20, 2018

Published: January 23, 2018

Copyright $\odot 2018$ by author and Scientific Research Publishing Inc. This work is licensed under the Creative Commons Attribution International License (CC BY 4.0).

http://creativecommons.org/licenses/by/4.0/

\begin{abstract}
Because Taiwan is export-oriented and highly connected with the US in terms of trade, Quantitative Easing (QE) of the Federal Reserve System (FED) had significant negative impacts on Taiwan. We examine several possible solutions for these negative impacts via the Delphi technique and the Analytic Hierarchy Process, synthesizing judgements from experts. The empirical results point out that a "negative influence on international trade affairs" is the predominant main criteria, and "improvement of international trade and investment regulations", "easing the impact of increases in the prices of raw materials obtained internationally", and "raising the competitiveness of the nation's export industry" are important sub-criteria. Especially, "improvement of international trade and investment regulations" corresponds with the global imbalance phenomenon. To strengthen the trade environment in Taiwan, experts suggest that an overall improvement in balance of payment is necessary that encompasses investment activities and trade regulations. We look forward our results offering useful suggestions.
\end{abstract}

\section{Keywords}

Quantitative Easing(QE), Global Imbalance

\section{Introduction}

Since the subprime mortgage crisis in the US in 2008, there has been an economic recession there. Financial institution lending has contracted, thus diminishing consumption and employment in the US and lowering internal demand in the US. This crisis also threatened its corresponding trade partners, emerging countries in Asia, via lessening Asia's exports and further diminishing its GDP. This negative influence became a global contagion that further induced a global economic recession. Traditional monetary policies could not end the US eco- 
nomic recession, so the US applied Quantitative Easing (hereafter QE) policies. Since March 2009, the Federal Reserve System (hereafter FED) proposed QE policies in three rounds and Operation Twist (hereafter OT) in one round. This process was stopped in October 2014 since the US economy was getting better.

Although QE enforcement induced US economic expansion, the large US dollar supply depreciated the US dollar and appreciated Asian currencies. It also damaged export industries in Asia countries. When the US dollar depreciates, Asian currencies are relatively depreciated. To maintain competitiveness in the export industry, currencies in Asia began depreciation competition.

Because of the US QE policies, the interest rate in the US was lower. Speculators searched for higher-payoff objects overseas, and hot money (short-term capital) began to flow into Asian countries. Hot money flooded both the stock and the real estate markets, pushing up various asset prices and causing prices to deviate from their real value. When economic growth cannot catch up with rising asset prices, asset bubbles will burst.

Literature on this topic has pointed out that the negative impacts of US QE policies can be classified into four categories: "asset price bubbles", "inflation", "negative influence on international trade affairs", and "adverse impact on export industries" [1] [2] [3] [4].

The US is an important correspondent trade partner of Taiwan; thus, any policy of the FED will affect Taiwan significantly. The subprime mortgage crisis occurring from 2007 to 2008 started a financial depression worldwide with the collapse of financial institutions and high unemployment. The FED proposed QE policies to improve the US economy, but the global economy is still in a recession. If the FED enforces another QE policy once again, what responses should Taiwan take? What should we do to diminish this hurt?

Through the AHP, the Delphi technique, and synthesizing expert opinions, we attempt to propose several actions to eliminate the negative impact of US QE policies on Taiwan.

\section{Literature Review}

\subsection{Process of US QE Policy}

Because traditional monetary policies were unable to stop the recession, the FED conducted QE. The enforcement period ran from March 2009 to November 2014 , including QE in three rounds and OT in one round.

The first round of QE (QE1): The time period ran from March 2009 to March 2010, when the FED started buying 1.25 trillion dollars in mortgagebacked securities, 3 trillion dollars in Treasury notes, and 1.7 trillion dollars in Agency MBS, totally 1.725 trillion US dollars.

The second round of QE (QE2): Ran from November 2010 to June 2011, where the FED bought $\$ 600$ billion dollars' worth of Treasury securities.

Operation Twist (OT): The FED announced OT in September 2011, which ran to December 2012. The FED sold short-term government bonds and pur- 
chased long-term government bonds of the same value at one time. Hence, no additional money was printed.

The third round of QE (QE3): The FED announced the third round of QE in November of 2012. There's no definite end point for QE3. Due to its open-ended nature, it is called "QE-Infinity". It will continue until the US employment market becomes better.

Prolonged QE3: QE3 was prolonged. Although there's no definite deadline for the termination of QE3, in June of 2013, Ben Bernanke announced a "tapering off" of the Fed's QE policies contingent on continued US positive economic data. The FED announced the scaling back of its bond purchases in January of 2014 and began to taper off its purchases in January of 2014. Bond-buying programs were halted at the end of October 2014.

\subsection{The Negative Influence of US QE on Trade in Taiwan}

Based on the literature, we determined various negative influences of the US QE policies on Taiwan, separately for capital markets, the materials market, international trade affairs, and export industries. Four main categories of these negative influences were developed: "asset price bubbles", "inflation", "negative influence on international trade affairs", and "adverse impact on export industries" [1] [2] [3] [4].

\section{1) Asset price bubbles}

US QE policies induced lower short-term market interest rates. Speculators in the US invest overseas, creating a hot money outflow. US QE policies speeded up the international hot money flooding everywhere and raised the risks inherent in the global stock and housing markets. However, when the hot money left, it instantly raised asset prices, creating asset price bubbles.

In response to the US QE policies, the increasing money supply in Taiwan boosted both stock prices and housing prices. Due to the possibility of asset price bubbles, the government in Taiwan took action. According to the literature, we propose three ways to ease these inverse impacts [1] [2] [3] [4] as follows:

a) Control hot money flooding into Taiwan originating from US QE policies

US QE policies depreciated the US dollar and relatively appreciated Asian currencies. Thus, lots of hot money flowed into Asia countries. To avoid asset price bubbles, it is necessary to properly control the inflow of hot money.

b) Increasing interest rates instantly as needed

QE policies are mainly enforced via government bond-purchasing, causing bond prices to rise and market interest rates to decrease, thus motivating speculators to invest on higher-payoff objects overseas. Hence, increasing interest rates properly and on a timely basis could lead to the absorption of hot money and alert speculators.

c) Raising the transaction cost of assets 
The Central Bank should engage in moral suasion, reminding banks not to deliberately set mortgage rates at lower levels. Also, related tax measures, such as levying securities taxes and housing taxes, also depress speculation.

We treat "control hot money originating from US QE policies flooding into Taiwan", "increasing interest rate instantly as needed", and "raising the transaction cost of assets" as sub-criteria for eliminating asset price bubbles originating from QE policies.

\section{2) Inflation}

Hot money flow into material markets, raises raw material prices and spurs inflation due to the speculation phenomenon. Central banks thus start to apply monetary contraction to cool down over-heated economies [1] [2] [3] [4].

In addition, governments should reduce import tariffs on necessities, which could both increase supplies and eliminate the inflation originating from shortages of such goods. As an alternative, governments could offer subsidies to firms in exchange for their more stable commodity prices. Hence, decreasing tariffs and offering subsidies as necessary by the government are important sub-criteria for eliminating the negative impact of QE policies on inflation.

In conclusion, we treat "raising up interest rate to reduce monetary supply", "depressing the inflation of raw materials", and "decreasing tariffs and offering subsidies moderated by the government" as sub-criteria for eliminating the negative impact of QE policies on inflation.

\section{3) Negative influence on international trade affairs}

Because international raw materials are valued in US dollars, with a depreciated US dollar, cheaper raw materials will cause countries to buy more, thus raising the demand that will immediately raise prices. When the US dollar is depreciated, the currencies of Asian countries are relatively appreciated. Although the price of raw materials is increased, we can appreciate our nation's currency relative to the US dollar, to ease the impact of increases in the prices of raw materials obtained internationally.

In September 2016, the G20 created tasks for the global economy, including a controlled, sequentially structured economic revolution, green investment expansion, anti-trade protection, and infrastructure improvement. Especially, maintaining control of the structured revolution is very important because imbalances will threaten the worldwide economy, and trade protection efforts will again threaten economic stability [5].

Currently, various types of imbalances occur, including twin fiscal and trade deficits in developed countries and the loosening of international trade and investment regulations, which further lead to global imbalances. Global imbalance has been shown to be a huge problem worldwide, representing current account deficits in developed countries (the US and Europe) relative to current account surpluses in developing countries (Asia). Thus, "improving international trade and investment regulations" should be stressed.

In conclusion, we treat "appreciating our nation's currency relative to the US 
dollar to ease the impact of increases in the prices of raw materials obtained internationally", "maintaining control of the structured economic revolution to ease trade friction" and "improvement of international trade and investment regulations" as sub-criteria for eliminating the negative influence of QE policies on international trade affairs.

\section{4) Adverse impact on export industries}

In the current volatile financial environment and shortened global business cycle, businesses have to try to sustain themselves. Hence, "raising the nation's export industry competitiveness" is important. Furthermore, in response to violent international competition, businesses in Taiwan should secure their management, innovation, and marketing capabilities as well as controlling risks and increasing R \& D. Therefore, specialization in unique industry brands in Taiwan should be stressed.

US QE policies depreciated the US dollar, and Asian currencies were thus relatively appreciated while accompanied by Asia's deteriorating economy and increased trade friction.

Hence, the central banks in Asia interfered with the exchange rate to protect their export industries, and their adaptations worked well. Therefore, "stable local currency appreciation relative to currencies in other countries" should be stressed.

In conclusion, we focus on "raising a nation's export industry competitiveness", "stabilizing local currency appreciation relative to currencies in other countries", and "specialization of the unique brand of industries in Taiwan" as three sub-criteria in eliminating adverse impacts on export industries originating from US QE policies.

\section{Empirical Methods}

Our procedure follows two stages. In the first stage, the Delphi technique is applied to choose the initial criteria combined with the judgements of experts to determine methods for eliminating the negative impact of US QE policies on Taiwan. In the second stage, we use analyses of the first stage as a foundation of the AHP to extract the weights of the criteria.

\subsection{First Stage: The Delphi Technique}

The Delphi technique is a communication method, an interactive forecasting method relying on experts' answers to questionnaires. The facilitator designs a questionnaire that is sent to a group of experts, and the results are summarized after the questionnaires are returned. Then, the facilitator develops a new questionnaire for the respondent group based on the results, and the experts then fill out questionnaires in two or more rounds. A communication process is structures, and the process is effective in allowing experts to revise their earlier answers based on the replies of others in this group [6] [7].

The facilitator provides an anonymized summary of the experts' forecasts 
from the previous round at each round. During this process, the number of answers will decrease, and the experts will converge towards the "correct" answer. After a predefined stop criterion, the process is stopped, and the mean scores of the final rounds determine the results.

\subsection{Second Stage: The Analytic Hierarchy Process (AHP)}

The AHP measures priority scales through pairwise comparisons and relies on the judgements of experts. Because the characteristics of the AHP are evaluating the weights of each criteria, the results of questionnaires can depend on priority scales to extract which important criteria is dominant over another with respect to a given attribute. The alternatives of a decision are ranked according to many criteria and sub-criteria. Because the criteria may be intangible, it might be not easy to weigh the priorities of alternatives to obtain their rankings. The design of the questionnaires can be accomplished through pairwise comparisons for the convenience of calculating weights, and the consistency is also tested. Hence, the foundation of the second stage is the AHP [8] [9] [10] [11].

If decision making involves many intangibles, then we measure using pairwise comparisons and judgements from experts to derive priority scales. The scales measure intangibles in relative terms through a scale of absolute judgements by comparing one criteria to another, with respect to a given attribute.

Because the judgements may be inconsistent, it is important to measure inconsistency and improve the judgements. The relative importance between two criteria is numerically scaled from 1 to 9 , and those located in a range from 5 to 9 will be the proper results [12]. The relative scores for the criteria in this study are shown in Table 1.

The procedure of evaluating methods for eliminating the negative impact of US QE policies on Taiwan is as follows:

\section{Step 1: Checking consistency}

When we perform pairwise comparisons, inconsistencies may easily occur. Therefore, it is necessary to check the consistency via a consistency index (C.I.). [13] proposed checking consistency using a consistency index (C.I.) and a consistency ratio (C.R.), where the consistency index is defined as follows:

$$
\mathrm{CI}=\frac{\lambda_{\max }^{K}-N}{N-1}
$$

CI: Consistency Index;

$\lambda_{\max }^{K}$ : the maximum eigenvalue of Matrix $\tilde{A}$;

$N$ : the number of evaluation criteria considered.

Random index (RI), the consistency index of a randomly generated reciprocal matrix, which ranges from 1 to 9 with reciprocals forced for each matrix size. Table 2 is the values of the random index. The consistency ratio, C.R. = C.I./R.I., where C.R. $<0.1$ indicates tolerable inconsistencies, and a reliable result may be expected from the AHP. Otherwise, it should be revised and adjusted accordingly. 
Table 1. Relative scores.

\begin{tabular}{ccc}
\hline Value & Interpretation & Value of $\boldsymbol{a}_{\boldsymbol{j} \boldsymbol{k}}$ \\
\hline 1 & Equal Importance & $(1,1,2)$ \\
2 & Between & $(1,2,3)$ \\
3 & Weak Importance & $(2,3,4)$ \\
4 & Between & $(3,4,5)$ \\
5 & Essential Importance & $(4,5,6)$ \\
6 & Between & $(5,6,7)$ \\
7 & Very Strong Importance & $(6,7,8)$ \\
8 & Between & $(7,8,9)$ \\
9 & Absolute Importance & $(8,9,9)$ \\
\hline
\end{tabular}

Source: Miller (1965).

Table 2. Random index.

\begin{tabular}{cccccccccccccccc}
\hline Matrix order & 1 & 2 & 3 & 4 & 5 & 6 & 7 & 8 & 9 & 10 & 11 & 12 & 13 & 14 & 15 \\
\hline RI. & 0.00 & 0.00 & 0.58 & 0.90 & 1.12 & 1.24 & 1.32 & 1.41 & 1.45 & 1.49 & 1.51 & 1.48 & 1.56 & 1.57 & 1.59
\end{tabular}

Source: Satty (1990).

\section{Step 2: Hierarchy structuring}

The hierarchy is structured with the decision goal at the top, followed by the intermediate levels to the lowest level, with the objectives being derived from a broad perspective. To get a perfectly consistent comparison judgment and perform pairwise comparison more easily, there should be fewer than 7 elements in each level.

\section{Step 3: Design an answer questionnaire for experts}

We designed the questionnaires as a pairwise comparison by synthesizing the responses from the experts to form a pairwise comparison matrix.

Step 4: Form a square pair-wise comparison matrix, $\tilde{A}=\left[\tilde{a}_{i j}\right]$

Synthesizing pair-wise comparison responses to form a square pair-wise comparison matrix, where $\tilde{A}$ is positive and is a reciprocal if the paired comparison judgment is perfectly consistent. That is,

$$
\tilde{a}_{i j}=\frac{1}{\tilde{a}_{j i}}, \forall i, j=1,2, \cdots, n .
$$

In matrix $\tilde{A}$, each entry $a_{i j}$ represents the importance of the $i$ th criterion relative to the $t$ th criterion. If $a_{i j}<1$ then the $i$ th criterion is less important than the $j$ th criterion; otherwise, the $i$ th criterion is more important than the th criterion

if $a_{i j}>1 . a_{i j}=1$ if two criteria have the same importance.

$\tilde{A}=\left[\tilde{a}_{i j}\right], \quad \tilde{A}:$ a square pair-wise comparison matrix, $\tilde{a}_{i j}=\left(l_{i j}, m_{i j}, u_{i j}\right)$.

\section{Step 5: Synthesize judgements}


The geometrical mean average method is used to synthesize the judgements by the experts, for which the equation is as follows:

$$
\tilde{a}_{i j}=\left(\tilde{a}_{i j}^{1} \otimes \tilde{a}_{i j}^{2} \otimes \cdots \otimes \tilde{a}_{i j}^{n}\right)^{\frac{1}{n}}
$$

$\tilde{a}_{i j}^{n}$ : “judgement of $\tilde{a}_{i j}$ ” from the Nth expert.

\section{Step 6: Computing the vector of criteria weights}

We use the geometrical mean average method to weight the criteria. In this way, we can also obtain normalization.

$$
\begin{gathered}
r_{i}=\left(\tilde{a}_{i 1} \otimes \tilde{a}_{i 2} \cdots \otimes \tilde{a}_{i n}\right)^{\frac{1}{n}} \\
\tilde{w}_{i}=r_{i} \otimes\left(r_{1} \oplus r_{2} \oplus \cdots \oplus r_{n}\right)^{-1}
\end{gathered}
$$

$r_{i}$ : geometrical mean in matrix $\tilde{A}$;

$\tilde{w}_{i}$ : weights of each row in the reciprocal matrix.

\section{Step 7: Eliminate intangibles}

To optimize each criterion, we must eliminate intangibles. The advantages of adopting $D F_{i j}$ are objectivity, where the experts' preferences can be ignored.

$$
D F_{i j}=\frac{a+b+c}{3}
$$

$a, b$, and $c$ are the upper value $u_{i j}$, middle value $m_{i j}$, and lower value $l_{i j}$, respectively.

\section{Step 8: Normalization}

To compare the importance of various criteria, we normalize the weights.

$$
N W_{i}=\frac{D F_{i j}}{\sum D F_{i j}}
$$

\section{Step 9: The final priorities}

Use the priorities obtained from the comparisons to weigh the criteria in the level immediately below. Do this for each element in the level below, and add its weight to obtain this overall priority. By continuing to weigh and add in this manner, we can obtain the final priorities of the alternatives in the bottom level.

From steps 1 to 8 , we get $N W_{i}$ and $N W_{i j}$, and the final priorities of the alternatives in the bottom level, as follows:

$$
N W_{j}=N W_{i} \times N W_{i j} .
$$

\section{Empirical Results}

\subsection{Analysis of Expert Results}

First, the questionnaires are constructed using the Delphi technique, and then we analyze the judgements from experts. Evaluation standards are averages that should be larger than 3 , and coefficients of variation should be less than 0.5 . In the first round, we issued 96 questionnaires, returning 74 effective questionnaires, and the response rate was $77.08 \%$. We issued questionnaires to 22 professors, 52 experts in financial institutions (research fellow in securities compa- 
nies, banks), for which the percentages were respectively $29.73 \%$ and $70.27 \%$. In the second round, the questionnaires constructed in the AHP, we issued 96 questionnaires, returning 70 effective questionnaires, for which the response rate was $72.92 \%$. We issued questionnaires to 22 professors and 48 experts in financial institutions, and the percentages were, respectively, $31.43 \%$ and $68.57 \%$.

\subsection{Results of the Questionnaires Using the Delphi Technique}

We synthesized the responses for the pairwise comparison and used the geometrical mean average method to weight the factors, corresponding to the major criteria and the sub-criteria. Through ranking, we chose the top 12 factors. The results of the questionnaires are shown in Table 3. If the result is $\mathrm{O}$, this indicates that the experts had consistent opinions. Otherwise, $\mathrm{X}$ indicates they had different opinions.

The 12 items selected using the Delphi technique are shown in Table 3. Their coefficient variations are all smaller 0.5, representing the consistency of the experts' opinions. For the next step, we designed a questionnaire using the AHP method, structured with four criteria and 12 sub-criteria.

Table 3. Results for methods chosen using the Delphi technique.

\begin{tabular}{|c|c|c|c|c|}
\hline Item & Option & Average & $\begin{array}{l}\text { Coefficient of } \\
\text { Variation }\end{array}$ & Result \\
\hline 1 & $\begin{array}{l}\text { Control the flood of hot money into Taiwan } \\
\text { originating from US QE policies }\end{array}$ & 3.7 & 0.32 & $\mathrm{O}$ \\
\hline 2 & Raising interest rates instantly as necessary & 3.4 & 0.35 & $\mathrm{O}$ \\
\hline 3 & Increasing the transaction cost of assets & 3.6 & 0.22 & $\mathrm{O}$ \\
\hline 4 & $\begin{array}{l}\text { Decreasing tariffs and offering subsidies } \\
\text { moderated by the government }\end{array}$ & 3.7 & 0.27 & $\mathrm{O}$ \\
\hline 5 & $\begin{array}{l}\text { Raising interest rates to reduce the } \\
\text { monetary supply }\end{array}$ & 3.1 & 0.27 & $\mathrm{O}$ \\
\hline 6 & $\begin{array}{l}\text { Easing the impact of increases in the prices } \\
\text { of raw materials obtained internationally }\end{array}$ & 3.1 & 0.30 & $\mathrm{O}$ \\
\hline 7 & $\begin{array}{l}\text { Appreciating the nation's currency relative } \\
\text { to the US dollar to ease the impact from } \\
\text { increases in the prices of raw materials } \\
\text { obtained internationally }\end{array}$ & 3.1 & 0.23 & $\mathrm{O}$ \\
\hline 8 & $\begin{array}{l}\text { Controlling the structured revolution to } \\
\text { ease trade friction }\end{array}$ & 3.9 & 0.18 & $\mathrm{O}$ \\
\hline 9 & $\begin{array}{l}\text { Improvement of international trade and } \\
\text { investment regulations }\end{array}$ & 4 & 0.27 & $\mathrm{O}$ \\
\hline 10 & $\begin{array}{l}\text { Increasing the competitiveness of the } \\
\text { nation's export industry }\end{array}$ & 4.4 & 0.15 & $\mathrm{O}$ \\
\hline 11 & $\begin{array}{l}\text { Stable local currency appreciation relative to } \\
\text { currencies in other countries }\end{array}$ & 4 & 0.16 & $\mathrm{O}$ \\
\hline 12 & $\begin{array}{l}\text { Specialization in the unique brand of } \\
\text { industries in Taiwan }\end{array}$ & 4.4 & 0.15 & $\mathrm{O}$ \\
\hline
\end{tabular}




\subsection{Results of the Questionnaire Using the AHP Method}

Since the expert judgements achieved consistency, we created a pairwise comparison matrix, evaluating the weights of each criteria. The results are shown in Table 4 and Table 5.

Among the main criteria for eliminating the negative impact of the US QE policies, "negative influence on international trade affairs (0.322)" was found to be the most important main criteria; then, sequentially in order of importance were "inflation (0.255)", "adverse impact on export industries (0.212)" and "asset price bubbles $(0.211)$ ".

As for the sub-criteria, the top 5 were "improvement in regulations on International trade and investment (0.166)", "Easing the impact from increases in the prices of raw materials obtained internationally $(0.125)$ ", "increasing the competitiveness of the nation's export industry (0.113)", "controlling the structured revolution to ease trade friction (0.106)", and "controlling the flood of hot money originating from the US QE into Taiwan (0.101)".

Table 4. Weight of major criteria and sub-criteria.

\begin{tabular}{|c|c|c|c|c|c|c|c|}
\hline \multirow[b]{2}{*}{ Goal } & \multicolumn{3}{|c|}{ Weight } & \multirow[b]{2}{*}{ Option } & \multicolumn{3}{|c|}{ Weight } \\
\hline & Lower bound & Median & Upper bound & & $\begin{array}{l}\text { Lower } \\
\text { bound }\end{array}$ & Median & Upper bound \\
\hline \multirow{4}{*}{$\begin{array}{l}\text { Asset price } \\
\text { bubbles }\end{array}$} & \multirow{3}{*}{0.64} & \multirow{3}{*}{0.86} & \multirow{3}{*}{1.15} & $\begin{array}{l}\text { Control hot money flooding into Taiwan } \\
\text { originating from US QE policies }\end{array}$ & 1.20 & 1.55 & 1.86 \\
\hline & & & & Raising interest rates instantly as necessary & 0.55 & 0.67 & 0.85 \\
\hline & & & & Increasing the transaction cost of assets & 0.75 & 0.96 & 1.30 \\
\hline & \multirow{3}{*}{0.79} & \multirow{3}{*}{1.02} & \multirow{3}{*}{1.39} & $\begin{array}{l}\text { Decreasing tariffs and offering subsidies } \\
\text { moderated by the government }\end{array}$ & 0.55 & 0.78 & 1.19 \\
\hline \multirow[t]{2}{*}{ Inflation } & & & & $\begin{array}{l}\text { Raising interest rates to reduce the } \\
\text { monetary supply }\end{array}$ & 0.58 & 0.80 & 1.15 \\
\hline & & & & $\begin{array}{l}\text { Easing the impact of increases in the prices of } \\
\text { raw materials obtained internationally }\end{array}$ & 1.08 & 1.61 & 2.13 \\
\hline \multirow{3}{*}{$\begin{array}{l}\text { Negative } \\
\text { influence on } \\
\text { international trade } \\
\text { affairs }\end{array}$} & \multirow{3}{*}{0.96} & \multirow{3}{*}{1.34} & \multirow{3}{*}{1.73} & $\begin{array}{l}\text { Appreciating the nation's currency relative to } \\
\text { the US dollar to ease the impact of } \\
\text { increases in the prices of raw materials obtained } \\
\text { internationally }\end{array}$ & 0.39 & 0.49 & 0.71 \\
\hline & & & & $\begin{array}{l}\text { Controlling the structured } \\
\text { revolution to ease trade friction }\end{array}$ & 0.83 & 1.14 & 1.46 \\
\hline & & & & $\begin{array}{l}\text { Improvement of international trade and in- } \\
\text { vestment regulations }\end{array}$ & 1.30 & 1.79 & 2.25 \\
\hline \multirow{3}{*}{$\begin{array}{c}\text { Adverse impact } \\
\text { on export } \\
\text { industries }\end{array}$} & \multirow{3}{*}{0.63} & \multirow{3}{*}{0.86} & \multirow{3}{*}{1.19} & $\begin{array}{l}\text { Increasing the competitiveness of the } \\
\text { nation's export industry }\end{array}$ & 1.37 & 1.93 & 2.35 \\
\hline & & & & $\begin{array}{l}\text { Stable local currency appreciation relative to } \\
\text { currencies in other countries }\end{array}$ & 0.36 & 0.45 & 0.65 \\
\hline & & & & $\begin{array}{l}\text { Specialization in the unique brand of } \\
\text { industries in Taiwan }\end{array}$ & 0.87 & 1.15 & 1.53 \\
\hline
\end{tabular}


Table 5. Relative weight and ranking.

\begin{tabular}{|c|c|c|c|c|c|}
\hline Goal & weight & Option & weight & Eliminate intangibles & Ranking \\
\hline \multirow{3}{*}{ Asset price bubbles } & \multirow{3}{*}{0.211} & $\begin{array}{l}\text { Control hot money flooding into Taiwan originating from } \\
\text { US QE policies }\end{array}$ & 0.478 & 0.101 & 5 \\
\hline & & Raising interest rates instantly as necessary & 0.214 & 0.045 & 11 \\
\hline & & Increasing the transaction cost of assets & 0.308 & 0.065 & 8 \\
\hline \multirow{3}{*}{ Inflation } & \multirow{3}{*}{0.255} & $\begin{array}{l}\text { Government-controlled decreases in tariffs and the offering } \\
\text { of subsidies as necessary }\end{array}$ & 0.252 & 0.064 & 9 \\
\hline & & Increasing interest rates to reduce monetary supply & 0.257 & 0.066 & 7 \\
\hline & & $\begin{array}{l}\text { Easing the impact from increases in the prices of raw } \\
\text { materials obtained internationally }\end{array}$ & 0.490 & 0.125 & 2 \\
\hline \multirow{3}{*}{$\begin{array}{l}\text { Negative influence on } \\
\text { international trade } \\
\text { affairs }\end{array}$} & \multirow{3}{*}{0.322} & $\begin{array}{l}\text { Appreciating the nation's currency relative to the US dollar, } \\
\text { to ease the impact of increases in the prices of raw materials } \\
\text { obtained internationally }\end{array}$ & 0.153 & 0.049 & 10 \\
\hline & & Controlling the structured revolution to ease trade friction & 0.331 & 0.106 & 4 \\
\hline & & $\begin{array}{l}\text { Improvement of international trade and investment } \\
\text { regulations }\end{array}$ & 0.516 & 0.166 & 1 \\
\hline \multirow{3}{*}{$\begin{array}{l}\text { Adverse impact on } \\
\text { export industries }\end{array}$} & \multirow{3}{*}{0.212} & $\begin{array}{l}\text { Increasing the competitiveness of the nation's } \\
\text { export industry competitiveness }\end{array}$ & 0.531 & 0.113 & 3 \\
\hline & & $\begin{array}{l}\text { Stable local currency appreciation relative to } \\
\text { currencies in other countries }\end{array}$ & 0.136 & 0.029 & 12 \\
\hline & & Specialization in the unique brand of industries in Taiwan & 0.333 & 0.071 & 6 \\
\hline
\end{tabular}

The results of the AHP are shown in Table 6, where we examine the consistency using $\mathrm{CI}$ and $\mathrm{CR}$ by showing the (C.R.) and (C.R.H.) of the returned questionnaires to all be smaller than 0.1 , indicating the overall consistency of the expert judgements.

The experts concluded that the most important criteria is to resolve "the negative influence on international trade affairs", and three important sub-criteria were, respectively, "improvement of international trade and investment regulations", "easing the impact of increases in the price of raw materials obtained internationally", and "increasing the competitiveness of the nation's export industry".

As for "improvement of international trade and investment regulations", the experts emphasized the regulation of investment activities in financial accounts and trade affairs in current accounts.

Nowadays, currency deficits in developed countries (the US and Europe), and currency surpluses in emerging markets (Asia) lead to global imbalance [14] [15] [16] [17]. Global imbalances may induce economic erosion in a complex way. Because Taiwan is an export-oriented area, the experts suggested Taiwan should face this issue.

As for "easing the impact of increases in the prices of raw materials obtained internationally", the US enforced the QE policies and the hot money pushed up the prices of raw materials. To reduce the prices, the central banks adopted a contracting monetary policy. 
Table 6. Checking of consistency index and consistency ratio.

\begin{tabular}{ccccc}
\hline & C.I. & Qualified & C.R. & Qualified \\
\hline Asset price bubbles & 0.002 & Yes & 0.003 & Yes \\
Inflation & 0.002 & Yes & 0.003 & Yes \\
$\begin{array}{c}\text { Negative influence on } \\
\text { international trade affairs } \\
\text { Adverse impact on export } \\
\text { industries }\end{array}$ & 0.007 & Yes & 0.012 & Yes \\
$\begin{array}{c}\text { Overall consistency } \\
\text { C.R.H. }=0.023<0.1, \text { satisfying the overall consistency }\end{array}$ \\
\hline
\end{tabular}

As for "raising the competitiveness of the nation's export industry", the competition among Asian currencies originated from the US QE policies. Because Taiwan relies heavily on exports, the experts suggested that businesses should adapt to the various global environments.

\section{Conclusions}

Applying the AHP to measure priority scales using pairwise comparisons and relying on the judgements of experts, we assess methods for eliminating negative impact originating US QE policies on Taiwan.

The most important main criterion was the "negative influence on international trade affairs". Among the sub-criteria, the experts focused on "improvement of international trade and investment regulations", "easing the impact of increases in the prices of raw materials obtained internationally", and "raising the competitiveness of the nation's export industry".

It should be noted that our results correspond to the global imbalance phenomenon [14] [15] [16] [17]. Because Taiwan is an export-oriented area, the experts focused on international trade and investment regulations, thus attempting to consider the possible economic damage caused from global imbalance. Some extensions will be enforced in the future. The granger-causality of those negative impacts will be stressed, and we focus on the interrelationships between criteria. We expect our conclusions to offer useful suggestions.

\section{References}

[1] Aizenman, J., Binici, M. and Hutchison, M.M. (2016) The Transmission of Federal Reserve Tapering News to Emerging Financial Markets. International Journal of Central Banking, 12, 317-356.

[2] Chari, A., Stedman, K.D. and Lundblad, C. (2017) Taper Tantrums: QE, Its Aftermath and Emerging Market Capital Flows. NBER Working Paper 23474.

[3] Chen, J., Mancini Griffoli, T. and Sahay, R. (2014) Spillovers from United States Monetary Policy on Emerging Markets: Different This Time? IMF Working Paper No. 14/240.

[4] Krishnamurthy, A. and Vissing-Jorgensen, A. (2011) The Effects of Quantitative Easing on Interest Rates: Channels and Implications for Policy. Brookings Papers on Economic Activity, 215-287. https://doi.org/10.1353/eca.2011.0019

[5] Wei, L. (2013) A Perspective on the Impact of Trade Friction on Customs Perfor- 
mance. World Customs Journal, 7, 81-92.

[6] Linstone, H.A. and やTuroff, M. (1975) Delphi Method: Techniques and Applications. Addison-Wesley Publishing Company, Reading.

[7] Murry, J.W. and Hammons, J.O. (1995) Delphi: A Versatile Methodology for Conducting Qualitative Research. The Review of Higher Education, 18, 426-436. https://doi.org/10.1353/rhe.1995.0008

[8] Laarhoven, P.J.M. and Pedrycz, W. (1983) A Fuzzy Extension of Saaty's Priority Theory. Fuzzy Sets and Systems, 11, 199-227. https://doi.org/10.1016/S0165-0114(83)80082-7

[9] Mai, C.C. (1981) Optimal Location and the Theory of the Firm under Demand Uncertainty. Regional Science and Urban Economics, 11, 549-557. https://doi.org/10.1016/0166-0462(81)90037-5

[10] Saaty, T.L. (1990) How to Make a Decision: The Analytic Hierarchy Process. European Journal of Operational Research, 48, 9-26. https://doi.org/10.1016/0377-2217(90)90057-I

[11] Saaty, T.L. (2008) Decision Making with the Analytic Hierarchy Process. International Journal of Services Sciences, 1, 83-98. https://doi.org/10.1504/IJSSCI.2008.017590

[12] Miller, G.A. (1965) The Magic Number Seven Plus or Minus Seven. Psychological Review, 63, 81-97. https://doi.org/10.1037/h0043158

[13] Saaty, T.L. (1980) The Analytic Hierarchy Process. McGraw-Hill, New York.

[14] Gourinchas, P.O. and Rey, H. (2007) From World Banker to World Venture Capitalist: US External Adjustment and the Exorbitant Privilege. In: Clarida, R.H., Ed., G7 Current Account Imbalances. Sustainability and Adjustment, Chicago Scholarship Online, 11-66. https://doi.org/10.7208/chicago/9780226107288.003.0002

[15] Gourinchas, P.O. and Rey, H. (2007b) International Financial Adjustment. Journal of Political Economy, 115, 665-702. https://doi.org/10.1086/521966

[16] Hausmann, R. and Sturzenegger, F. (2006) Global Imbalance or Bad Accounting? The Missing Dark Matter in the Wealth of Nations. Working Paper Series 06-003, Harvard University, John F. Kennedy School of Government.

[17] Hausmann, R. and Sturzenegger, F. (2007) The Missing Dark Matter in the Wealth of Nations and Its Implications for Global Imbalances. Economic Policy, 22, 469-518. https://doi.org/10.1111/j.1468-0327.2007.00182.x 